\title{
Pertumbuhan dan Hasil Tanaman Selada (Lactuca sativa L.) yang Diaplikasi Teh Kompos, Teh Guano, PGPR, dan Ekstrak Biochar
}

Eugenia Dos Reis ${ }^{\mathrm{a}}$,

${ }^{a}$ Fakultas Pertanian, Universitas Timor, Kefamenanu, TTU-NTT, Indonesia, email: eugeniadosreis2019@ gmail.com

\section{Article Info}

Article history:

Received 11 Desember 2019

Received in revised form 27 Februari 2020 Accepted 25 Maret 2020

DOI:

https://doi.org/10.32938/sc.v5i02.901

\section{Keywords:}

Selada (Lactuca sativa L. )

Teh Kompos

Teh Guano

PGPR

Ekstrak Biochar

\section{Abstrak}

Tujuan penelitian untuk mengetahui pengaruh kombinasi teh kompos, teh guano, ekstrak biochar, PGPR terhadap pertumbuhan dan hasil selada darat.Penelitian ini telah dilakukan dari bulan Mei 2019 sampai bulan Juli 2019, dilahan percobaan Fakultas Pertanian, Universitas Timor. Desain penelitian menggunakan Rancangan Acak Lengkap (RAL) faktor tunggal 12 perlakuan 3 ulangan. Perlakuan terdiri dari: tanah kosong (T0), tanah +Teh kompos (T1), tanah + teh kompos + teh guano (T2), tanah + teh kompos + teh guano + PGPR (T3), tanah + teh kompos + ekstrak biochar (T4), Tanah + teh kompos + ekstrak biochar + PGPR (T5), tanah + PGPR (T6), tanah + teh kompos + PGPR (T7), tanah + teh guano (T8), tanah + teh guano + PGPR (T9), tanah + ekstrak biochar (T10), tanah + ekstrak biochar + PGPR (T11). Perlakuan tersebut diulang 3 kali sehingga terdapat 36 unit pot penelitian. Hasil sidik ragam anova menunjukkan bahwa perlakuan terbaik terdapat pada kombinasi teh guano + PGPR yang diekspresikan melalui parameter jumlah daun ,berat segar daun, berat segar total, panjang akar, berat kering daun, berat kering total, dan indeks panen

\section{Pendahuluan}

Selada (Lactuca sativa L.) merupakan sayuran daun yang berasal dari daerah (negara) beriklim sedang. Menurut sejarahnya, tanaman selada telah dibudidayakan sejak 2500 tahun yang lalu. Tanaman selada berasal dari kawasan Amerika. Hal ini dibuktikan oleh Christoper Columbus pada tahun 1493 yang menemukan tanaman selada didaerah Hemisphere bagian barat dan Bahamas (AAK,1994). Selanjutnya Wicaksono, (2008) menyatakan selada disukai oleh masyarakat, karena jenis sayur ini mengandung zat-zat gizi seperti protein, vitamin $\mathrm{B}$, vitamin $\mathrm{C}$ untuk memenuhi kebutuhan gizi masyarakat Selada sebagai bahan makanan dapat dikomsumsi dalam bentuk segar sebagai lalapan yang dimakan bersama dengan bahan makanan lain. Selada juga salah satu jenis tanaman sayuran yang dikonsumsi daunnya.

Prospek serapan pasar terhadap komoditas selada akan terus meningkat sejalan dengan peningkatan jumlah penduduk, peningkatan pendidikan masyarakat, peningkatan pendapatan dan kesejahteraan masyarakat,dan peningkatan kesukaan (preferensi) masyarakat terhadap selada (Samadi, 2014). Pembuatan biochar memerlukan air untuk memadamkan api dan mendinginkan biochar hasil pembakaran. Diduga bahwa air yang digunakan untuk memadamkan dan mendinginkan biochar mengandung kation, anion dan senyawa organik dalam konsentrasi yang tinggi.Senyawa-senyawa organik yang larut air dari biochar terdiri dari humat, asam-asam organik bermolekul rendah, unsur-unsur anorganik yang terdiri dari unsur makro dan mikro, diketahui berperan penting terhadap pertumbuhan tanaman. Senyawa-senyawa dalam ekstrak biochar dapat berperan sebagai nutrisi tanaman dan stimulan pertumbuhan. Ekstrak biochar merupakan larutan (fitrat) hasil perendaman biochar selama beberapa waktu.Ekstrak biochar diduga mengandung kationkation basa yang berada dipermukaan biochar. Kation-kation ini diharapkan dapat memperkaya kation-kation pada media tumbuh selada. Pemberian ekstrak biochar diharapkan mempermudah tanaman selada dalam menyerap hara dari biochar melalui permukaan daun.

PGPR merupakan konsorsium bakteri yang aktif mengkolonisasi akar tanaman yang berperan penting dalam meningkatkan pertumbuhan tanaman, hasil panen dan kesuburan lahan (Gusti et al., 2012). Prinsip pemberian PGPR adalah meningkatkan jumlah bakteri yang aktif di sekitar perakaran tanaman sehingga memberikan keuntungan bagi tanaman. Keuntungan penggunaan PGPR adalah meningkatkan kadar mineral dan fiksasi nitrogen, meningkatkan toleransi tanaman terhadap cekaman lingkungan, sebagai biofertilier, agen biologi control, melindungi tanaman dari patogen tumbuhan serta peningkatan produksi indol-3-acetic acid (IAA) (Figuiredo et al., 2010).

Teh kompos makin meningkat pemanfaatannya terutama bagi pengembangan pertanian organik, karena fungsi gandanya baik sebagai penyedia hara, hormon tumbuh, maupun sebagai agen biokontrol penyakit tanaman.Manfaat utama dari teh kompos adalah: (1) meningkatkan tekanan terhadap penyakit atau ketahanan terhadap serangan patogen, dan meningkatkan kesehatan tanaman sehingga meangurangi penggunaan pestisida, (2) suplai hara terlarut bagi tanaman sehingga mengurangi penggunaan pupuk, (3) meningkatkan populasi, diversitas dan aktivitas mikroorganisme tanah yang berperan dalam perbaikan struktur tanah, retensi air, penetrasi akar dan pertumbuhan tanaman (Recycled Organics Unit, 2006). Pupuk guano tidak hanya dapat merangsang pertumbuhan dengan baik, namun guano juga dapat tahan lama tinggal di dalam jaringan tanah, dapat meningkatkan produktifitas tanah dan juga menyediakan nutrisi bagi tanaman dalam jumlah yang lebih banyak dari pada pupuk kimia buatan (Grantina et al., 2015). Pemberian teh guano pada tanaman selada yaitu dapat memperbaiki ketersediaan unsur hara,meningkatkan aktivitas mekroorganisme tanah dan dapat memperbaiki sifat fisik tanah. Pemberian teh guano diharapkan lebih efektif diserap oleh selada melalui permukaan daunnya.Selada merupakan tanaman berdaun. Pemberian ekstrak biochar, PGPR, dan teh guano diharapkan lebih efektif diserap oleh permukaan daun sehingga meningkatkan pertumbuhan dan hasil tanaman selada. Selain pemberian hara melalui permukaan daun, pemberian teh kompos juga diharapkan memicu pertumbuhan selada sehingga meningkatkan hasil tanaman selada.

\section{Metode}

Penelitian ini dilakukan pada bulan Mei sampai Juli 2019 di Kebun Fakultas Pertanian Universitas Timor, Kelurahan Sasi Kecamatan Kota Kefamenanu, Kabupaten Timor Tengah Utara, Provinsi Nusa Tenggara Timur. Penelitian ini dilakukan dengan Percobaan pot menggunakan Rancangan Acak Lengkap (RAL) faktor tunggal 12 perlakuan 3 ulangan. Perlakuan terdiri dari tanah kosong $\left(\mathrm{T}_{0}\right)$, tanah + teh kompos $\left(\mathrm{t}_{1}\right)$, tanah + teh kompos + teh guano(t2), tanah+ teh kompos + teh guano + PGPR (t3), tanah + teh kompos + ekstrak biochar (t4), tanah + teh kompos + ekstrak biochar + PGPR (T5), tanah + PGPR (T6), tanah + teh kompos + PGPR (T7), tanah + teh guano (T8), tanah+ teh guano + PGPR (T9), Tanah + ekstrak biochar (T10), Tanah + ekstrak biochar + PGPR (T11). Perlakuan tersebut diulang 3 kali sehingga terdapat 36 unit pot penelitian.

\section{Hasil dan Pembahasan \\ 3.1 Hasil \\ Suhu Tanah}

Suhu tanah merupakan hasil dari keseluruhan radiasi yang merupakan kombinasi panjang gelombang dan aliran panas dalam tanah dengan suhu tanah sangat bervariasi. Sejalan dengan perubahan proses pertukaran energi matahari, terutama melalui permukaan tanah (Lubis, 2007). Hasil sidik ragam anova menunjukkan bahwa terjadi beda nyata antar perlakuan yang signifikan. Hasil uji lanjut DMRT menunjukkan bahwa perlakuan tanah + ekstrak biochar menghasilkan suhu tanah paling tinggi yang berbeda sangat nyata dengan perlakuan tanah + teh kompos + ekstrak biochar (Tabel 1).

\section{Tabel 1. Suhu Tanah $\left({ }^{\circ} \mathrm{C}\right) 28$ Hari Setelah Tanam (HST)}

\begin{tabular}{lc}
\hline \multicolumn{1}{c}{ Perlakuan } & Suhu 28 HST \\
\hline Tanah & $28,73 \mathrm{abc}$ \\
Tanah + Teh Kompos & $27,80 \mathrm{abcd}$ \\
Tanah + Teh Kompos + Teh quano & $27,86 \mathrm{abcd}$ \\
Tanah + Teh Kompos + Teh Guano + PGPR & $27,00 \mathrm{abcd}$ \\
Tanah + Teh Kompos + Ekstrak biochar & $25,83 \mathrm{~d}$ \\
Tanah + Teh Kompos + ekstrak biochar + PGPR & $26,66 \mathrm{bcd}$ \\
Tanah + PGPR & $28,93 \mathrm{abc}$ \\
Tanah + Teh Kompos + PGPR & $26,46 \mathrm{~cd}$ \\
Tanah + Teh guano & $27,96 \mathrm{abcd}$ \\
Tanah + Teh guano + PGPR & $29,10 \mathrm{ab}$ \\
Tanah + Ekstrak biochar & $29,33 \mathrm{a}$ \\
Tanah + Ekstrak biochar + PGPR & $26,43 \mathrm{~cd}$ \\
\hline
\end{tabular}

Signifikansi

Keterangan: Angka yang diikuti oleh huruf yang sama menunjukkan tidak berbeda nyata pada uji DMRTa $=0,05 .(* *)$ Pengaruh sangat nyata antar perlakuan.

\section{Kadar Lengas Tanah}

Pada penelitian digunakan ekstrak biochar, teh komps, teh guano, dan larutan PGPR yang menjadi sumber lengas selain air. Tanaman membutuhkan kandungan lengas dalam jumlah optimal di daerah perakaran selama masa 
pertumbuhan. Hasil sidik ragam anova menunjukkan bahwa tidak terjadi pengaruh antar perlakuan. Hasil uji lanjut DMRT menunjukkan bahwa pada awa pengamatan untuk parameter kelengasan menghasilkan beda nyata antar perlakuan Tanah + PGPR menghasilkan kelengasan tanah yang paling tinggi yang berbeda sangat nyata dengan perlakuan Tanah + ekstrak biochar + PGPR tetapi pada akhir pengamatan tidak terjadi beda nyata antar perlakuan (Tabel. 2)

\section{Tabel 2. Kadar lengas Tanah $(\%)$}

\begin{tabular}{lcc}
\hline \multicolumn{1}{c}{ Perlakuan } & $\begin{array}{c}\text { Kadar } \\
\text { Lengas } \\
\text { Awal }\end{array}$ & $\begin{array}{c}\text { Kadar } \\
\text { Lengas } \\
\text { Akhir }\end{array}$ \\
\hline Tanah & $17,54 \mathrm{bc}$ & $37,09 \mathrm{a}$ \\
Tanah + Teh Kompos & $23,64 \mathrm{ab}$ & $36,07 \mathrm{a}$ \\
Tanah + Teh Kompos + Teh quano & $21,86 \mathrm{abc}$ & $57,87 \mathrm{a}$ \\
Tanah + Teh Kompos + Teh Guano + PGPR & $24,30 \mathrm{ab}$ & $38,88 \mathrm{a}$ \\
Tanah + Teh Kompos + Ekstrak biochar & $24,26 \mathrm{ab}$ & $39,98 \mathrm{a}$ \\
Tanah + Teh Kompos + ekstrak biochar + PGPR & $23,55 \mathrm{ab}$ & $34,57 \mathrm{a}$ \\
Tanah + PGPR & $26,10 \mathrm{a}$ & $37,75 \mathrm{a}$ \\
Tanah + Teh Kompos + PGPR & $19,14 \mathrm{abc}$ & $40,15 \mathrm{a}$ \\
Tanah + Teh guano & $22,21 \mathrm{abc}$ & $48,61 \mathrm{a}$ \\
Tanah + Teh guano + PGPR & $21,91 \mathrm{abc}$ & $39,48 \mathrm{a}$ \\
T anah + Ekstrak biochar & $22,34 \mathrm{abc}$ & $37,35 \mathrm{a}$ \\
Tanah + Ekstrak biochar + PGPR & $15,19 \mathrm{c}$ & $36,61 \mathrm{a}$ \\
\hline Signifikansi & $\mathrm{NS}$ & $\mathrm{NS}$
\end{tabular}

Keterangan : Angka yang diikuti oleh huruf yang sama menunjukkan tidak berbeda nyata pada uji DMRT $\alpha=0,05$., (NS): tidak terjadi beda nyata yang signifikan.

\section{Berat Volume Tanah}

Berat volume tanah adalah perbandingan berat tanah kering dengan satuan volume tanah. Berat volume tanah merupakan petunjuk kepadatan tanah dimana semakin padat suatu tanah, maka makin tinggi berat volumenya, artinya semakin sulit meneruskan air atau di tembus akar tanaman. tanah yang lebih padat mempunyai berat volume lebih besar dari tanah yang sama tetapi kurang padat.

$\underline{\text { Tabel 3. Berat Volume Tanah }\left(\mathrm{g} / \mathrm{cm}^{3}\right)}$

\begin{tabular}{lcc}
\hline \multicolumn{1}{c}{ Perlakuan } & $\begin{array}{c}\text { Berat } \\
\text { Volume } \\
\text { Awal }\end{array}$ & $\begin{array}{c}\text { Berat } \\
\text { Volume } \\
\text { Akhir }\end{array}$ \\
\hline Tanah & $1,0 \mathrm{c}$ & $1,2 \mathrm{ab}$ \\
Tanah + Teh Kompos & $1,9 \mathrm{ab}$ & $1,5 \mathrm{ab}$ \\
Tanah + Teh Kompos + Teh quano & $1,5 \mathrm{abc}$ & $1,4 \mathrm{ab}$ \\
Tanah + Teh Kompos + Teh Guano + PGPR & $1,4 \mathrm{bc}$ & $1,3 \mathrm{ab}$ \\
Teh + Teh Kompos + Ekstrak biochar & $1,2 \mathrm{bc}$ & $1,2 \mathrm{ab}$ \\
Tanah + Teh Kompos + ekstrak biochar + PGPR & $1,2 \mathrm{bc}$ & $1,1 \mathrm{ab}$ \\
Tanah + PGPR & $1,2 \mathrm{bc}$ & $1,6 \mathrm{~b}$ \\
Tanah + Teh Kompos + PGPR & $1,8 \mathrm{ab}$ & $1,2 \mathrm{ab}$ \\
Tanah + Teh guano & $1,4 \mathrm{bc}$ & $1,0 \mathrm{ab}$ \\
Tanah + Teh guano + PGPR & $2,1 \mathrm{a}$ & $1,3 \mathrm{ab}$ \\
Tanah + Ekstrak biochar & $1,6 \mathrm{abc}$ & $0,9 \mathrm{a}$ \\
Tanah + Ekstrak biochar + PGPR & $1,5 \mathrm{abc}$ & $1,2 \mathrm{ab}$ \\
\hline Signifikansi & $* *$ & $\mathrm{NS}$ \\
\hline Teran
\end{tabular}

Keterangan : Angka yang diikuti oleh huruf yang sama menunjukkan tidak berbeda nyate pada uji DMRT $\alpha=0,05$., (NS): tidak terjadi beda nyata yang signifikan. : (**) Pengaruh sangat nyata antar perlakuan.

Nilai berat volume tanah mineral berkisar 1-1,6 gr/cc, sedangkan tanah organik umumnya memiliki nilai berat volume tanah antara 0,1-0,9 gr/cc. Berat volume tanah dipengaruhi oleh tekstur, struktur dan kandungan bahan organik (Hardjowigeno,2007). Hasil sidik ragam anova menunjukkan bahwa pada awal pengamatan terjadi beda nyata perlakuan tetapi pada akhir pengamatan tidak terjadi beda nyata yang signifikan antar perlakuan. Hasil uji lanjut DMRT bahwa perlakuan Tanah (kontrol ) pada awal menghasilkan BV tanah paling rendah sangat berbeda dengan Tanah + teh guano + PGPR sedangkan pada akhir pengamatan perlakuan tanah + ekstrak biochar menghasilkan berat volume tanah paling rendah berbeda nyata dengan tanah + PGPR (Tabel. 3)

\section{pH Tanah}

$\mathrm{pH}$ tanah merupakan tingkat keasaman atau kebasaan suatu tanah. Hasil sidik ragam anova menunjukkan bahwa pada awal pengamatan tidak terjadi beda nyata yang signifikan tetapi terjadi beda nyata antar perlakuan yang signifikan pada akhir pengamatan. Hasil uji lanjut DMRT menunjukkan bahwa perlakuan tanah + the guano menghasilkan $\mathrm{pH}$ tanah paling rendah yang berbeda sangat nyata dengan perlakuan lainnya pada awal pengamatan, sedangkan pada akhir pengamatan perlakuan tanah + ekstrak biochar + PGPR menghasilkan $\mathrm{pH}$ tanah paling rendah yang berbeda sangat nyata dengan perlakuan lainnya (Tabel. 4)

\section{Daya Hantar Listrik}

Daya hantar listrik tanah adalah kemampuan tanah untuk menghantarkan arus listrik. Daya hantar listrik tanah terjadi karena eksistensi kandungan garam bebas yang terdapat pada kadar air tanah dan kandungan ion dapat ditukar yang terdapat pada permukaan partikel pada tanah (Rhoades et al., 1999). Hasil sidik ragam anova menunjukkan bahwa pada tidak terjadi pengaruh antar perlakuan. Hasil uji lanjut DMRT bahwa pada awal pengamatan untuk daya hantar listrik menghasilkan beda nyata antar perlakuan tanah + teh kompos + ekstrak biochar + PGPR menghasilkan daya hantar listrik tanah paling tinggi yang berbeda sangat nyata dengan perlakuan tanah + ekstrak biochar tetapi pada akhir pengamatan perlakuan tanah + teh guano+ PGPR menghasilkan daya hantar listrik yang paling tinggi yang berbeda sangat nyata dengan perlakuan tanah + teh kompos (Tabel. 5)

Tabel 4. $\mathrm{pH}$ tanah

\begin{tabular}{lcc}
\hline \multicolumn{1}{c}{ Perlakuan } & $\mathrm{pH}$ Awal & pH Akhir \\
\hline Tanah & $5,9 \mathrm{a}$ & $5,9 \mathrm{a}$ \\
Tanah + Teh Kompos & $5,9 \mathrm{a}$ & $6,5 \mathrm{a}$ \\
Tanah + Teh Kompos + Teh Guano & $5,9 \mathrm{a}$ & $6,5 \mathrm{a}$ \\
Tanah + Teh Kompos + Teh Guano + PGPR & $5,9 \mathrm{a}$ & $6,2 \mathrm{a}$ \\
Teh + Teh Kompos + Ekstrak biochar & $6,0 \mathrm{a}$ & $6,0 \mathrm{a}$ \\
Tanah + Teh Kompos + ekstrak biochar + PGPR & $6,0 \mathrm{a}$ & $5,9 \mathrm{a}$ \\
Tanah + Pgpr & $6,0 \mathrm{a}$ & $6,0 \mathrm{a}$ \\
Tanah + Teh Kompos + Pgpr & $6,0 \mathrm{a}$ & $5,9 \mathrm{a}$ \\
Tanah + Teh guano & $5,3 \mathrm{~b}$ & $6,3 \mathrm{a}$ \\
Tanah + Teh guano + PGPR & $5,9 \mathrm{a}$ & $6,4 \mathrm{a}$ \\
Tanah + Ekstrak biochar & $5,9 \mathrm{a}$ & $6,0 \mathrm{a}$ \\
Tanah + Ekstrak biochar + PGPR & $6,0 \mathrm{a}$ & $4,6 \mathrm{~b}$ \\
\hline & $\mathrm{NS}$ & $* *$
\end{tabular}

Keterangan : Angka yang diikuti oleh huruf yang sama menunjukkan tidak berbeda nyata pada uji DMRT $\alpha=0,05$., (NS): tidak terjadi beda nyata yang signifikan. : (**) Pengaruh sangat nyata antar perlakuan.

Tabel 5. Daya Hantar Listrik (dS/M²)

\begin{tabular}{lcc}
\multicolumn{1}{c}{ Perlakuan } & $\begin{array}{c}\text { Daya Hantar } \\
\text { Listrik Awal }\end{array}$ & $\begin{array}{c}\text { Daya Hantar } \\
\text { Listrik Akhir }\end{array}$ \\
\hline Tanah & $133 \mathrm{bc}$ & $367 \mathrm{abc}$ \\
Tanah + Teh Kompos & $153 \mathrm{abc}$ & $164 \mathrm{c}$ \\
Tanah + Teh Kompos + Teh quano & $157 \mathrm{abc}$ & $286 \mathrm{abc}$ \\
Tanah + Teh Kompos + Teh Guano + PGPR & $141 \mathrm{abc}$ & $617 \mathrm{ab}$ \\
Teh + Teh Kompos + Ekstrak biochar & $145 \mathrm{abc}$ & $281 \mathrm{abc}$ \\
Tanah + Teh Kompos + ekstrak biochar + PGPR & $192 \mathrm{a}$ & $410 \mathrm{abc}$ \\
Tanah + PGPR & $147 \mathrm{abc}$ & $423 \mathrm{abc}$ \\
Tanah + Teh Kompos + PGPR & $178 \mathrm{ab}$ & $223 \mathrm{bc}$ \\
Tanah + Teh guano & $160 \mathrm{abc}$ & $470 \mathrm{abc}$ \\
Tanah + Teh guano + PGPR & $151 \mathrm{abc}$ & $638 \mathrm{a}$ \\
Tanah + Ekstrak biochar & $123 \mathrm{c}$ & $380 \mathrm{abc}$ \\
Tanah + Ekstrak biochar + PGPR & $145 \mathrm{abc}$ & $385 \mathrm{abc}$ \\
\hline & $\mathrm{NS}$ & $\mathrm{NS}$ \\
\hline
\end{tabular}

Keterangan : Angka yang diikuti oleh huruf yang sama menunjukkan tidak berbeda nyata pada uji DMRT $\alpha=0,05$., (NS): tidak terjadi beda nyata yang signifikan.

\section{Tinggi Tanaman}

Tinggi tanaman merupakan salah satu faktor utama untuk mengetahui langsung pengaruh lingkungan dan perlakuan yang diberikan pada suatu tanaman serta efesiensi penggunaan hara tanaman (Sitompul \& Guritno 1995). Tanaman tumbuh tegak setinggi 30-7 berbentuk bulat kecil. Hasil sidik ragam anova menunjukkan bahwa pada Tinggi tanaman pada pengamatan7 HST, 14 HST, 21 HST, 28 HST,35 HST tidak terjadi beda nyata yang signifikan tetapi pada pengamatan Tinggi tanaman 42 HST terjadi beda nyata. Hasil uji lanjut DMRT Pada tinggi tanaman 42 hstmenghasilkan beda nyata antar perlakuan tanah + teh kompos+teh guano+PGPR rmenghasilkan Tinggi tanaman paling tinggi yangberbeda sangat nyata dengan perlakuan tanah + teh kompos + ekstrak biochar dan tanah + teh kompos + ekstrak biochar PGPR (Tabel 6)

\section{Jumlah Daun}

Jumlah daun merupakan faktor utama yang menentukan kualitas pertumbuhan dan kemampuan fotosintesis suatu tanaman. Hasil sidik ragam anova menunjukkan bahwa pada jumlah daun pada pengamatan7 hst, $14 \mathrm{hst}, 21$ hst tidak terjadi beda nyata yang signifikan tetapi pada pengamatan jumlah daun 28 hst, 35 hst, 42 hst terjadi beda nyata. Hasil uji lanjut DMRT bahwa pada pengamatan 42 hst menghasilkan beda nyata antar perlakuan tanah + teh kompos + teh guano dan tanah + teh guano + PGPR menghasilkan jumlah daun paling tinggi yang berbeda sangat nyata dengan perlakuan tanah + teh kompos + ekstrak biochar dan tanah teh kompos + ekstrak biochar (Tabel 7)

\section{Berat Segar Total}

Pertumbuhan tanaman membentuk bagian tanaman seperti daun, batang dan akar. Hasil sidik ragam anova menunjukkan bahwa terjadi beda nyata antar perlakuan yang signifikan. Hasil uji lanjut DMRT bahwa pada perlakuan tanah + teh kompos + teh guano dan tanah + teh guano + PGPR menghasilkan berat segar tanaman yang paling tinggi berbeda sangat nyata dengan perlakuan tanah + teh kompos + ekstrak biochar (Tabel 8) 


\section{Berat Segar Daun}

Selada merupakan tanaman sayuran berdaun karena daun merupakan bagian utama yang dikonsumsi, sehingga peningkatan jumlah daun dan total berat daun menjadi salah satu parameter penting. Hasil sidik ragam anova menunjukkan bahwa terjadi beda nyata antar perlakuan yang signifikan.

Tabel 6. Tinggi Tanaman $(\mathrm{cm})$

\begin{tabular}{|c|c|c|c|c|c|}
\hline Perlakuan & TT 7 & TT 14 & TT 21 & TT 28 TT 35 & TT 42 \\
\hline Tanah & $5,33 \mathrm{abc}$ & $\mathrm{c}$ & $73 \mathrm{a}$ &, 66 a 15,66 a & $17,33 \mathrm{bc}$ \\
\hline Tanah + Teh Kompos & $6,47 \mathrm{a}$ & $8,83 a b c$ & $13,56 \mathrm{a}$ & 15,93 a 17,93 a & $20,23 a b c$ \\
\hline $\begin{array}{l}\text { Tanah + Teh Kompos } \\
+ \text { Teh quano }\end{array}$ & $5,26 \mathrm{abc}$ & $8,06 \mathrm{abc}$ & $12,70 \mathrm{a}$ & 15,60 a 17,30 a & $20,40 \mathrm{abc}$ \\
\hline $\begin{array}{l}\text { Tanah + Teh Kompos } \\
\text { + Teh Guano + PGPR }\end{array}$ & $5,00 a b c$ & $10,26 \mathrm{a}$ & $13,16 \mathrm{a}$ & 15,56 a 17,66 a & 21,33 a \\
\hline $\begin{array}{l}\text { Tanah + Teh Kompos } \\
+ \text { Ekstrak biochar }\end{array}$ & $5,40 a b c$ & $9,73 a b c$ & $12,03 \mathrm{a}$ & 14,46 a 16,10 a & $17,06 \mathrm{c}$ \\
\hline $\begin{array}{l}\text { Tanah + Teh Kompos } \\
+ \text { ekstrak biochar + } \\
\text { PGPR }\end{array}$ & $5,00 a b c$ & $8,63 a b c$ & $12,60 \mathrm{a}$ & 14,46 a 15,56 a & $17,06 \mathrm{c}$ \\
\hline Tanah + PGPR & $3,96 \mathrm{c}$ & $7,86 \mathrm{bc}$ & $12,36 \mathrm{a}$ & 15,00 a 16,10 a & $18,06 \mathrm{abc}$ \\
\hline $\begin{array}{l}\text { Tanah + Teh Kompos } \\
+ \text { PGPR }\end{array}$ & $5,46 \mathrm{abc}$ & $9,00 \mathrm{abc}$ & $13,20 \mathrm{a}$ & 15,00 & $17,20 \mathrm{c}$ \\
\hline Tanah + Teh guano & $5,46 a b c$ & $9,50 a b c$ & $11,83 \mathrm{a}$ & 13,93 a 15,50 a & $21,13 a b$ \\
\hline $\begin{array}{l}\text { Tanah + Teh guano + } \\
\text { PGPR }\end{array}$ & $5,03 a b c$ & $9,43 a b c$ & $13,16 \mathrm{a}$ & 16,46 a 17,46 a & $19,83 a b c$ \\
\hline $\begin{array}{l}\text { Tanah + Ekstrak } \\
\text { biochar }\end{array}$ & $5,83 \mathrm{ab}$ & $10,10 \mathrm{ab}$ & $12,16 \mathrm{a}$ & 13,73 a 15,13 & $17,33 \mathrm{bc}$ \\
\hline $\begin{array}{l}\text { Tanah + Ekstrak } \\
\text { biochar + PGPR } \\
\end{array}$ & $4,63 \mathrm{bc}$ & $9,00 a b c$ & $13,50 \mathrm{a}$ & 13,73 a 17,80 a & $19,73 a b c$ \\
\hline & NS & NS & NS & NS & ** \\
\hline
\end{tabular}

Tabel 7. Jumlah daun ((Helai)

\begin{tabular}{lcccccc}
\hline \multicolumn{1}{c}{ Perlakuan } & JD 7 & JD 14 & JD21 & JD 28 & JD 35 & JD 42 \\
\hline Tanah & $2,66 \mathrm{a}$ & $3,66 \mathrm{abc}$ & $4,00 \mathrm{ab}$ & $4,66 \mathrm{bc}$ & $5,33 \mathrm{abc}$ & $6,00 \mathrm{bc}$ \\
Tanah + Teh Kompos & $2,66 \mathrm{a}$ & $3,66 \mathrm{abc}$ & $4,33 \mathrm{ab}$ & $5,33 \mathrm{abc} 6,00 \mathrm{abc}$ & $7,00 \mathrm{ab}$ \\
$\begin{array}{l}\text { Tanah + Teh Kompos } \\
\text { + Teh quano }\end{array}$ & $3,00 \mathrm{a}$ & $4,00 \mathrm{ab}$ & $5,00 \mathrm{a}$ & $6,00 \mathrm{a}$ & $6,66 \mathrm{a}$ & $7,66 \mathrm{a}$ \\
$\begin{array}{l}\text { Tanah + Teh Kompos } \\
\text { + Teh Guano + }\end{array}$ & $3,00 \mathrm{a}$ & $4,00 \mathrm{ab}$ & $4,66 \mathrm{ab}$ & $5,33 \mathrm{abc}$ & $6,33 \mathrm{ab}$ & $7,33 \mathrm{ab}$ \\
$\begin{array}{l}\text { PGPR } \\
\text { Tanah + Teh Kompos } \\
\text { + Ekstrak biochar }\end{array}$ & $3,00 \mathrm{a}$ & $3,33 \mathrm{bc}$ & $3,66 \mathrm{~b}$ & $4,33 \mathrm{c}$ & $4,66 \mathrm{c}$ & $5,33 \mathrm{c}$ \\
$\begin{array}{l}\text { Tanah + Teh Kompos } \\
\text { + ekstrak biochar + }\end{array}$ & $2,66 \mathrm{a}$ & $3,00 \mathrm{c}$ & $3,66 \mathrm{~b}$ & $4,33 \mathrm{c}$ & $5,00 \mathrm{bc}$ & $5,33 \mathrm{c}$ \\
PGPR & $3,00 \mathrm{a}$ & $3,66 \mathrm{abc}$ & $4,66 \mathrm{ab}$ & $5,66 \mathrm{ab}$ & $6,66 \mathrm{a}$ & $7,66 \mathrm{c}$ \\
$\begin{array}{l}\text { Tanah + PGPR } \\
\text { Tanah + Teh Kompos } \\
\text { + PGPR }\end{array}$ & $3,00 \mathrm{a}$ & $3,66 \mathrm{abc}$ & $4,00 \mathrm{ab}$ & $5,00 \mathrm{abc} 5,33 \mathrm{abc}$ & $6,33 \mathrm{abc}$ \\
$\begin{array}{l}\text { Tanah + Teh guano } \\
\text { Tanah + Teh guano + }\end{array}$ & $3,33 \mathrm{a}$ & $3,66 \mathrm{abc}$ & $4,66 \mathrm{ab}$ & $5,00 \mathrm{abc} 6,00 \mathrm{abc}$ & $7,00 \mathrm{ab}$ \\
$\begin{array}{l}\text { PGPR } \\
\text { Tanah + Ekstrak }\end{array}$ & $3,33 \mathrm{a}$ & $4,33 \mathrm{a}$ & $4,66 \mathrm{ab}$ & $5,66 \mathrm{ab}$ & $6,33 \mathrm{ab}$ & $7,66 \mathrm{a}$ \\
biochar & $2,66 \mathrm{a}$ & $3,66 \mathrm{abc}$ & $4,33 \mathrm{ab}$ & $4,66 \mathrm{bc}$ & $5,66 \mathrm{abc}$ & $6,66 \mathrm{abc}$ \\
$\begin{array}{l}\text { Tanah + Ekstrak } \\
\text { biochar + PGPR }\end{array}$ & $3,00 \mathrm{a}$ & $3,66 \mathrm{abc}$ & $4,33 \mathrm{ab}$ & $4,66 \mathrm{bc}$ & $5,66 \mathrm{abc}$ & $6,33 \mathrm{abc}$ \\
\hline
\end{tabular}

Keterangan: Angka yang diikuti oleh huruf yang sama menunjukkan tidak berbeda nyate pada uji DMRT a 0,05., (NS): tidak terjadi beda nyata yang signifikan.: (**) Pengaruh sangat nyata antar perlakuan

\section{Tabel 8. Berat Segar Total (g)}

\begin{tabular}{lc} 
Perlakuan & Berat Segar Total \\
\hline Tanah & $28,13 \mathrm{bc}$ \\
Tanah + Teh Kompos & $52,85 \mathrm{a}$ \\
Tanah + Teh Kompos + Teh quano & $52,85 \mathrm{a}$ \\
Tanah + Teh Kompos + Teh Guano + PGPR & $39,77 \mathrm{ab}$ \\
Tanah + Teh Kompos + Ekstrak biochar & $15,42 \mathrm{c}$ \\
Tanah + Teh Kompos + ekstrak biochar + PGPR & $18,84 \mathrm{bc}$ \\
Tanah + PGPR & $28,27 \mathrm{bc}$ \\
Tanah + Teh Kompos + PGPR & $24,70 \mathrm{bc}$ \\
Tanah + Teh guano & $42,45 \mathrm{ab}$ \\
Tanah + Teh guano + PGPR & $54,04 \mathrm{a}$ \\
Tanah + Ekstrak biochar & $26,69 \mathrm{bc}$ \\
Tanah + Ekstrak biochar + PGPR & $40,88 \mathrm{ab}$ \\
\hline
\end{tabular}

Keterangan : Angka yang diikuti oleh huruf yang sama menunjukkan tidak berbeda nyata pada uji DMRT $\alpha=0,05 .,(* *)$ : Pengaruhsangat nyata antar perlakuan.

\section{Berat Segar Akar}

Hasil sidik ragam anova menunjukkan bahwa tidak terjadi pengaruh antar perlakuan. Hasil uji lanjut DMRT bahwa pada semua perlakuan beda nayata yang signifikan (Tabel 10)

Tabel 9. Berat Segar Daun

\begin{tabular}{lc}
\hline \multicolumn{1}{c}{ Perlakuan } & Berat Segar Daun \\
\hline Tanah & $25,07 \mathrm{bcd}$ \\
Tanah + Teh Kompos & $50,66 \mathrm{a}$ \\
Tanah + Teh Kompos + Teh quano & $45,09 \mathrm{ab}$ \\
Tanah + Teh Kompos + Teh Guano + PGPR & $37,68 \mathrm{abc}$ \\
Teh + Teh Kompos + Ekstrak biochar & $13,51 \mathrm{~d}$ \\
Tanah + Teh Kompos + ekstrak biochar + PGPR & $16,69 \mathrm{~cd}$ \\
Tanah + PGPR & $29,10 \mathrm{abcd}$ \\
Tanah + Teh Kompos + PGPR & $22,41 \mathrm{bcd}$ \\
Tanah + Teh guano & $39,56 \mathrm{abc}$ \\
Tanah + Teh guano + PGPR & $50,93 \mathrm{a}$ \\
Tanah + Ekstrak biochar & $26,21 \mathrm{bcd}$ \\
Tanah + Ekstrak biochar + PGPR & $37,75 \mathrm{abc}$ \\
\hline
\end{tabular}

$\overline{\text { Keterangan : Angka yang diikuti oleh huruf yang sama menunjukkan tidak berbeda nyata }}$ pada uji DMRT $\alpha=0,05$., (**): Pengaruh sangat nyata antar perlakuan.

Hasil uji lanjut DMRT bahwa pada perlakuan tanah + teh guano menghasilkan berat segar daun yang paling tinggi berbeda sangat nyata dengan perlakuan tanah + teh kompos dan ekstrak biochar (Tabel 9)

Tabel 10. Berat Segar Akar (g)

\begin{tabular}{lc}
\hline \multicolumn{1}{c}{ Perlakuan } & Berat Segar Akar \\
\hline Tanah & $2,47 \mathrm{a}$ \\
Tanah + Teh Kompos & $2,53 \mathrm{a}$ \\
Tanah + Teh Kompos + Teh quano & $2,83 \mathrm{a}$ \\
Tanah + Teh Kompos + Teh Guano + PGPR & $2,51 \mathrm{a}$ \\
Teh + Teh Kompos + Ekstrak biochar & $1,86 \mathrm{a}$ \\
Tanah + Teh Kompos + ekstrak biochar + Pgpr & $2,24 \mathrm{a}$ \\
Tanah + PGPR & $2,05 \mathrm{a}$ \\
Tanah + Teh Kompos + PGPR & $2,44 \mathrm{a}$ \\
Tanah + Teh guano & $2,83 \mathrm{a}$ \\
Tanah + Teh guano + PGPR & $2,46 \mathrm{a}$ \\
Tanah + Ekstrak biochar & $2,29 \mathrm{a}$ \\
Tanah + Ekstrak biochar + PGPR & $3,13 \mathrm{a}$ \\
\hline
\end{tabular}

Keterangan : Angka yang diikuti oleh huruf yang sama menunjukkan tidak berbeda nyata pada uji DMRT $\alpha=0,05$., (NS): tidak terjadi beda nyata yang signifikan.

\section{Panjang Akar}

Tanaman selada menghasilkan akar tunggang dengan cepat dengan dibarengi dengan berkembang dan menebalnya akar lateral secara horizontal. Akar lateral tumbuh didekat permukaan tanah berfungsi untuk menyerap sebagian air dan hara (Cahyono, 2005).

Tabel 11. Panjang Akar (cm)

\begin{tabular}{lc}
\hline \multicolumn{1}{c}{ Perlakuan } & Panjang Akar \\
\hline Tanah & $14,16 \mathrm{a}$ \\
Tanah + Teh Kompos & $12,46 \mathrm{a}$ \\
Tanah + Teh Kompos + Teh quano & $10,83 \mathrm{a}$ \\
Tanah + Teh Kompos + Teh Guano + PGPR & $11,30 \mathrm{a}$ \\
Teh + Teh Kompos + Ekstrak biochar & $11,13 \mathrm{a}$ \\
Tanah + Teh Kompos + ekstrak biochar + PGPR & $11,50 \mathrm{a}$ \\
Tanah + PGPR & $10,63 \mathrm{a}$ \\
Tanah + Teh Kompos + Pgpr & $13,53 \mathrm{a}$ \\
Tanah + Teh guano & $11,70 \mathrm{a}$ \\
Tanah + Teh guano + PGPR & $9,53 \mathrm{a}$ \\
Tanah + Ekstrak biochar & $12,06 \mathrm{a}$ \\
Tanah + Ekstrak biochar + PGPR & $13,10 \mathrm{a}$ \\
\hline
\end{tabular}

Keterangan : Angka yang diikuti oleh huruf yang sama menunjukkan tidak berbeda nyata pada uji DMRT $\alpha=0,05$., (NS): tidak terjadi beda nyata yang signifikan.

Panjang akar mencerminkan keadaan hara di tanah. Semakin tinggi konsentrasi hara maka semakin pendek akar tanaman yang tumbuh. Hasil sidik ragam anova menunjukkan bahwa tidak terjadi pengaruh antar perlakuan. Hasil uji lanjut DMRT bahwa pada semua perlakuan beda nyata yang signifikan (Tabel 11)

\section{Berat Kering Total}

Berat kering total merupakan menghitung tanaman yang sudah di panen secara keseluruhan kemudian di di ovenkan selama 24 jam kemudian di timbang kembali secara total. Hasil sidik ragam anova menunjukkan bahwa tidak terjadi pengaruh antar perlakuan. Hasil uji lanjut DMRT menunjukan tanah + teh guano + pgpr menghasilkan berat kering total yang paling tinggi 
berbeda nyata dengan perlakuan tanah + teh kompos + ekstrak biochar + PGPR (Tabel 12).

\section{Tabel 12. Berat kering total (g)}

\begin{tabular}{lc}
\hline \multicolumn{1}{c}{ Perlakuan } & Berat Kering Total \\
\hline Tanah & $1,93 \mathrm{ab}$ \\
Tanah + Teh Kompos & $2,98 \mathrm{ab}$ \\
Tanah + Teh Kompos + Teh quano & $2,55 \mathrm{ab}$ \\
Tanah + Teh Kompos + Teh Guano + PGPR & $2,24 \mathrm{ab}$ \\
Teh + Teh Kompos + Ekstrak biochar & $1,69 \mathrm{ab}$ \\
Tanah + Teh Kompos + ekstrak biochar + PGPR & $1,28 \mathrm{~b}$ \\
Tanah + PGPR & $2,31 \mathrm{ab}$ \\
Tanah + Teh Kompos + PGPR & $1,65 \mathrm{ab}$ \\
Tanah + Teh guano & $2,57 \mathrm{ab}$ \\
Tanah + Teh guano + PGPR & $3,42 \mathrm{a}$ \\
Tanah + Ekstrak biochar & $2,33 \mathrm{ab}$ \\
Tanah + Ekstrak biochar + PGPR & $2,97 \mathrm{ab}$ \\
\hline
\end{tabular}

Keterangan : Angka yang diikuti oleh huruf yang sama menunjukkan tidak berbeda nyata pada ujiDMRT $\alpha=0,05$., (NS): Pengaruh sangat nyata antar perlakuan.

\section{Berat Kering Daun}

Berat kering daun merupakan daun yang sudah di timbang kemudian di ovenkan selama 24 jam kemudian di timbang kembali. Hasil sidik ragam anova menunjukkan bahwa tidak terjadi pengaruh antar perlakuan. Hasil uji lanjut DMRT menunjukan tanah + teh guano + PGPR menghasilkan berat kering daun yang paling tinggi berbeda nyata dengan perlakuan tanah + teh guano + ekstrak biochar + PGPR (Tabel 13)

$\underline{\text { Tabel 13. Berat Kering Daun (g) }}$

\begin{tabular}{lc}
\hline \multicolumn{1}{c}{ Perlakuan } & $\begin{array}{c}\text { Berat Kering } \\
\text { Daun }\end{array}$ \\
\hline Tanah & $1,70 \mathrm{ab}$ \\
Tanah + Teh Kompos & $2,71 \mathrm{ab}$ \\
Tanah + Teh Kompos + Teh quano & $2,16 \mathrm{ab}$ \\
Tanah + Teh Kompos + Teh Guano + PGPR & $1,95 \mathrm{ab}$ \\
Teh + Teh Kompos + Ekstrak biochar & $1,52 \mathrm{ab}$ \\
Tanah + Teh Kompos + ekstrak biochar + PGPR & $1,17 \mathrm{~b}$ \\
Tanah + PGPR & $2,12 \mathrm{ab}$ \\
Tanah + Teh Kompos + PGPR & $1,27 \mathrm{~b}$ \\
Tanah + Teh guano & $2,21 \mathrm{ab}$ \\
Tanah + Teh guano + PGPR & $3,16 \mathrm{a}$ \\
Tanah + Ekstrak biochar & $2,03 \mathrm{ab}$ \\
Tanah + Ekstrak biochar + PGPR & $2,44 \mathrm{ab}$ \\
\hline
\end{tabular}

Keterangan : Angka yang diikuti oleh huruf yang sama menunjukkan tidak berbeda nyata pada uji DMRT $\alpha=0,05$., (NS): tidak terjadi beda nyata yang signifikan

\section{Berat Kering Akar}

Berat kering akar merupakan akar yang sudah di timbang kemudian di ovenkan selama 24 jam kemudian di timbang kembali. Hasil sidik ragam anova menunjukkan bahwa tidak terjadi pengaruh antar perlakuan. Hasil uji lanjut DMRT bahwa pada semua perlakuan beda nyata yang signifikan (Tabel 14)

\section{Tabel 14. Berat Kering Akar (g)}

\begin{tabular}{lc}
\hline \multicolumn{1}{c}{ Perlakuan } & Berat Kering Akar \\
\hline Tanah & $0,47 \mathrm{a}$ \\
Tanah + Teh Kompos & $0,27 \mathrm{a}$ \\
Tanah + Teh Kompos + Teh quano & $0,26 \mathrm{a}$ \\
Tanah + Teh Kompos + Teh Guano + PGPR & $0,61 \mathrm{a}$ \\
Teh + Teh Kompos + Ekstrak biochar & $0,22 \mathrm{a}$ \\
Tanah + Teh Kompos + ekstrak biochar + PGPR & $0,21 \mathrm{a}$ \\
Tanah + PGPR & $0,18 \mathrm{a}$ \\
Tanah + Teh Kompos + PGPR & $0,30 \mathrm{a}$ \\
Tanah + Teh guano & $0,37 \mathrm{a}$ \\
Tanah + Teh guano + PGPR & $0,27 \mathrm{a}$ \\
Tanah + Ekstrak biochar & $0,57 \mathrm{a}$ \\
Tanah + Ekstrak biochar + PGPR & $0,54 \mathrm{a}$ \\
\hline
\end{tabular}

Keterangan : Angka yang diikuti oleh huruf yang sama menunjukkan tidak berbeda nyata pada uji DMRT a 0,05., (NS): tidak terjadi beda nyata yang signifikan.

\section{Indeks panen}

Indeks panen menunjukkan distribusi bahan kering dalam tanaman yang menunjukkan perimbangan bobot bahan kering yang bernilai ekonomis dengan total bobot bahan kering tanaman pada saat panen. Hasil sidik ragam anova menunjukkan bahwa terjadi beda nyata antar perlakuan yang signifikan. Hasi uji lanjut DMRT menunjukan tanah +teh guano + PGPR menghasilkan indeks panen yang paling tinggi berbeda sangat nyata dengan perlakuan tanah + ekstrak biochar + PGPR (Tabel 15)
Tabel 15. Indeks Panen (\%)

\begin{tabular}{lc}
\hline \multicolumn{1}{c}{ Perlakuan } & Indeks Panen \\
\hline Tanah & $91 \mathrm{abcd}$ \\
Tanah + Teh Kompos & $95 \mathrm{a}$ \\
Tanah + Teh Kompos + Teh quano & $94 \mathrm{a}$ \\
Tanah + Teh Kompos + Teh Guano + PGPR & $93 \mathrm{ab}$ \\
Teh + Teh Kompos + Ekstrak biochar & $88 \mathrm{~cd}$ \\
Tanah + Teh Kompos + ekstrak biochar + PGPR & $87 \mathrm{~d}$ \\
Tanah + PGPR & $93 \mathrm{ab}$ \\
Tanah + Teh Kompos + PGPR & $89 \mathrm{bcd}$ \\
Tanah + Teh guano & $93 \mathrm{a}$ \\
Tanah + Teh guano + PGPR & $95 \mathrm{a}$ \\
Tanah + Ekstrak biochar & $91 \mathrm{abcd}$ \\
Tanah + Ekstrak biochar + PGPR & $92 \mathrm{abc}$ \\
\hline
\end{tabular}

Keterangan : Angka yang diikuti oleh huruf yang sama menunjukkan tidak berbeda nyata pada ujiDMRT $\alpha=0,05 .,(* *)$ : Pengaruh sangat nyata antar perlakuan.

\subsection{Pembahasan}

Tanaman membutuhkan kandungan lengas dalam jumlah optimal di daerah perakaran selama masa pertumbuhan. Sumber utama tersedianya lengas tanah untuk tanaman adalah air dalam tanah yang kemudian dihisap oleh akar. Pada penelitian digunakan ekstrak biochar, teh kompos, teh guano, dan larutan PGPR yang menjadi sumber lengas selain air. Hasil penelitian menunjukkan perlakuan tanah + teh kompos + teh guano memberikan nilai kelengasan tertinggi yakni sebesar $57,87 \%$. Tanah dengan kandungan bahan organik rendah memiliki kemampuan mengikat air yang rendah dibanding tanah dengan kandungan bahan organik tinggi (Kurnia et al., 2006). Kandungan lengas tanah yang rendah menyebabkan akar tanaman menjadi sulit untuk menghisapnya sehingga mengakibatkan tanaman menjadi layu,sehingga panambahan bahan organik mengakibatkan kadar lengas meningkat yang berefek pada tanaman menjadi optimal pertumbuhannya. Hasil pengamatan secara keseluruhan terlihat bahwa semua perlakuan mengalami kenaikan nilai kelengasan tanah.

Pengamatan BV tanah menunjukkan bahwa pemberian teh kompos, teh guano dan ekstrak biochar mampu menurunkan nilai BV tanah dibanding pemberian PGPR dan kontrol. Ini diduga akibat adanya penambahan bahan organik mampu memperbaiki konsistensi tanah menjadi lebih baik. Berat volume tanah merupakan penunjuk kepadatan tanah. Makin padat suatu tanah, maka makin tinggi berat volume tanah. Nilai berat volune tanah sangat bervariasi dikarenakan perbedaan kandungan bahan organik, tekstur tanah, kedalaman tanah, jenis fauna tanah, dan kadar air tanah (Agus et al.,2006). Tanah dengan bahan organik yang tinggi mempunyai berat volume rendah.

Tanah + ekstrak biochar memberikan efek penurunan berat volume tanah menjadi $0,9 \mathrm{~g} / \mathrm{cm}^{3}$ dari awal pengamatan sebesar $1,6 \mathrm{~g} / \mathrm{cm}^{3}$ yang mana diduga akibat sumbangan bahan organik dari ekstrak biochar. Tanah yang mengandung bahan organik tinggi memiliki berat volume tanah rendah. Lou et al., (2016) mengungkapkan bahwa senyawa organik yang larut dalam air dari residu pirolisis yang mengandung zat humat, asam organik yang berbobot molekul rendah, dan unsur anorganik yang mengandung unsur hara makro dan mikro. Derajat keasaman tanah pada penelitian secara keseluruhan meningkat untuk semua perlakuan, kecuali pada perlakuan tanah + ekstrak biochar + PGPR yang menurun dari pH 6.0 menjadi 4.6 di akhir pengamatan.

Ini diduga akibat efek dari PGPR. Terlihat dari perlakuan yang mengandung PGPR seperti tanah + teh kompos + ekstrak biochar + PGPR, tanah + teh kompos + PGPR yang mengalami penurunan $\mathrm{pH}$. Hasil penelitian menunjukkan bahwa perlakuan untuk daya hantar listrik menghasilkan perlakuan tanah + tehkompos + ekstrak biochar + PGPR menghasilkan daya hantar listrik tanah paling tinggi di awal pengamatan dan pada akhir pengamatan perlakuan tanah + teh guano + PGPR menghasilkan daya hantar listrik yang paling tinggi. Daya hantar listrik hasil pengamatan menunjukkan kenaikan di akhir pengamatan peningkatan daya hantar listrik tanah berkaitan dengan pemberian bahanorganik dan kemampuan bahan organik untuk menghasilkan asam-asam organik.

Asam-asam organik yang dilepaskan sebagai akibat dekomposisi bahan organik yang banyak mengandung ion-ion basah sehingga meningkatkan DHL di akhir pengamatan. Pertumbuhan tanaman merupakan pertambahan volume, massa, jumlah protoplasma, dan atau jumlah sel. Dua macam pertambahan yang lazim digunakan untuk mengukur pertumbuhan adalah pertambahan volume dan massa. Pertambahan volume bisa ditentukan dengan cara mengukur perbesaran seperti batang, diameter batang dan panjang daun. Pertambahan massa sering ditentukan dengan cara mengukur berat basah dan berat kering suatu tanaman (Salisbury \& Ross 1995). Tanah + teh kompos + teh guano + PGPR dan Tanah + teh kompos + teh guano memberikan hasil pertumbuhan terbaik yang teramati pada parameter tinggi tanaman dan jumlah daun. Ini diduga akibat akumulasi nitrogen dari teh kompos dan teh guano. Fungsi unsur hara nitrogen bagi tanaman antara lain mendorong pertumbuhan tanaman secara keseluruhan (terlebih saat fase vegetatif), mendukung proses metabolisme seperti fototsintesis.

Teh kompos merupakan ekstrak air dari kompos yang telah matang (Ingham, 2005). Kompos mengandung unsur-unsur hara yang bermanfaat bagi tanaman dan ekosistem tanah sehingga aplikasinya ke dalam tanah dapat memperbaiki kesuburan tanah dan meningkatkan ketahanan tanaman terhadap 
patogen melalui aktivitas mikroba yang terkandung di dalamanya. Teh kompos dapat menambah substansi humus, hormon tumbuh dan enzim serta senyawasenyawa organik lain di dalam tanah (Pant et al., 2012).

Pengamatan daun yang mana sebagai organ fotosintat dilakukan sebagai indikator pertumbuhan yang dapat menggambarkan proses pertumbuhan yang terjadi seperti pembentukan biomassa. Berat kering total tanaman merupakan gambaran efisiensi dari proses fisiologis di dalam tanaman (Wulandari \& Susanti, 2012). Berat segar daun berbanding lurus dengan berat kering daun. Awal pertumbuhan tanaman akan membutuhkan nitrogen dalam jumlah banyak untuk menunjang pertumbuhan vegetative tanaman selada. Nitrogen yang diperoleh tanaman dari aplikasi ekstrak kompos dan ekstrak guano akan menunjang kebutuhan unsur $\mathrm{N}$ sehingga menjadi terpenuhi. Ini akan mengakibatkan jumlah sel bertambah banyak dan ukuran sel tanaman bertambah besar karena unsur nitrogen merupakan bahan utama penyusun asam amino pembentuk protein yang dibutuhkan dalam pembelahan sel.

Pertambahan jumlah dan ukuran sel ini akan memacu pertumbuhan organ-organ tanaman yakni daun dan akar yang terakumulasi pada berat kering organ-organ tersebut. Berat kering akar yang terbesar dihasilkan pada perlakuan tanah + teh kompos + teh guano + PGPR sama dengan tinggi tanaman pada 42 HST. Berat kering daun yang memberikan nilai terbesar adalah tanah + teh guano + PGPR yang sejalan dengan jumlah daun dan tinggi tanaman pada 28 HST.

Hasil penelitian menunjukkan bahwa pada parameter hasil, pada perlakuan Tanah + Teh Guano + PGPR memiliki nilai tertinggi,pada parameter pengamatan berat kering daun, berat kering total, berat segar daun, pada perlakuan tanah + teh kompos + teh guano memiliki nilai tertinggi para parameter berat segar daun, pada perlakuan Tanah memiliki nilai tertinggi pada panjang akar, pada perlakuan tanah + ekstrak biochar memiliki nilai tertinggi pada berat segar non ekonomi pada perlakuan tanah + teh guano + PGPR memiliki nilai tertinggi pada berat kering non ekonomi dan pada parameter indeks panen Tanah + teh kompos dan Tanah + teh + guano + PGPR memiliki nilai tertinggi.

Fotosintesis merupakan faktor dasar yang mepengaruhi proses pembentukan bahan kering tanaman. Akumulasi bahan kering pada daun, dan akar selama pertumbuhan vegetatif merupakan hasil utama yang dipanen dari tanaman hijauan. Berat kering total tanaman selada yang terbesar ditunjukkan oleh perlakuan tanah + teh guano + PGPR yang sama dengan jumlah daun pada pengamatan vegetatif tanaman. Perbandingan akumulasi bahan kering pada bagian ekonomis dengan bahan kering total dinyatakan dengan indeks panen. Indeks panen terbesar ditunjukkan oleh perlakuan tanah + teh guano+ PGPR dan tanah + teh kompos yakni sebesar $95 \%$.

\section{Simpulan}

Berdasarkan penelitian yang telah dilaksanakan diketahui bahwa hasi yang baik dari pengaruh kombinasi teh kompos, teh guano, ekstrak biochar, PGPR terhadap pertumbuhan dan hasil tanaman selada pada tanah entisol semi arid terjadi pada perlakuan kombinasi teh guano + PGPR yang diekspresikan melalui parameter jumlah daun berat segar daun, berat segar total, panjang akar, berat kering daun, berat kering total, dan indeks panen.

\section{Pustaka}

AAK 1994. Bertanam Selada \& Andewi. Jakarta: Kanisius.

Agus F, RD Yustika dan U Haryati. 2006. Penetapan Berat Volume Tanah. Di dalam Sifat Fisika Tanah dan Metode Analisisnya. Balai Besar Litbang Sumberdaya Lahan Pertanian. Badan Penelitian dan Pengembangan Pertanian, Bogor

Cahyono.2005. Budidaya Tanaman Sayuran. Penebar Swadaya. Jakarta. 117 hlm.

Figuiredo. M., Seldin. L. Araujo. F. \& Mariano. R. (2010). Plant Growth Promoting Rhizobacteria : Fundamentals and Applications. Microbiology Monographs (18)

Grantina, L., Levina, and G. Levinsh. 2015. Microbiological Characteristics And Effect

Gusti, I.N., Khalimi, K.,. Dewa, I.N. Ketut., \& Dani, S. (2012). Aplikasi Rhizobacteri Pantoea agglomerans untuk Meningkatkan Pertumbuhan Dan Hasil Tanaman Jagung. (Zea mays.L) Varietas hibrida BISI-2.Agrotrop. 2 (1):1-9.

Hardjowigeno, S. 2007. Ilmu Tanah. Akademia Pressindo, Jakarta. 288 hal.

Ingham, E. R. 2005. The compost tea brewing manual. Soil Foodweb Inc. Oregon, USA.

Kurnia, A. dan Notodiputro, K.A. 2006. Penerapan Metode Jackknife dalam Pendugaan Area Kecil. Forum Statistika dan Komputasi ISSN 0853-8115 Vol.11 No.1

Pant, A. P., Radovich, T.J.K, Hue, N.V., Paull, R. E. 2012b. Biochemicalproperties of compost tea associated with compost quality and effects on pakchoi growth. Scientia Horticulturae 148 : 138-146.

Pant, A. P., Radovich, T.J.K, Hue, N.V., Paull, R. E. 2012b. Biochemicalproperties of compost tea associated with compost quality and effects on pakchoi growth. Scientia Horticulturae 148 : 138-146.
Recycled Organics Unit. 2006. Overview of compost tea use in New South Wales. Recycled Organics Unit, internet publication: www recycle d organics. com

Rhoades JD, Chanduvi F, Lesch S. 1999. Soil Salinity Assesment: Method AndInterpretation of Electrical Conductivity Measurement. Roma (IT): FAO United Nations

Salisbury, F. B. dan C. W. Ross. 1995. Fisiologi Tumbuhan, Perkembangan Tumbuhan, dan Fisiologi Lingkungan. Institut Teknologi Bandung, Bandung

Samadi, B. 2014. Rahasia Budidaya Selada. Depok: Pustaka Mina.

Sitompul, S. M. dan Guritno, B. 1995. Analisis Pertumbuhan Tanaman. UGM Press: Yogjakarta

Wicaksono 2008. Morfologi Tanaman Sayuran. Yogyakarta: Gajah Mada University Press.

Wulandari, A.S. dan Susanti, S. 2012. Aplikasi Pupuk Daun Organik untuk Meningkatkan Pertumbuhan Bibit Jabon (Anthocephalus cadamba Roxb. Miq.).

Y. Lou, S. Joseph, L. Li, E.R. Graber, X. Liu, G. Pan, Water extract from straw biochar used for plant growth promotion: an initial test, BioResources 11 (1) (2016) 249-266. 